\title{
Knee Osteoarthritis: Conservative or Surgical Treatment?
}

\author{
Leonardo Domínguez Plain ${ }^{1}$, Claribel Plain Pazos², Sergio Morales Piñeiro ${ }^{3}$, Juan Carlos Cedré González ${ }^{4}$, \\ Anisbel Pérez de Alejo Plain ${ }^{5}$ and Yanet Flores Mirabal ${ }^{6}$ \\ ${ }^{1} 2^{\text {nd }}$ year Orthopedic Resident, Universitary Hospital "Mártires del 9 de Abril", Cuba \\ ${ }^{2}$ Specialist of I and II Degree in Comprehensive General Medicine, Assistant Professor, Faculty of Medical Sciences of Sagua la Grande, Cuba \\ ${ }^{3}$ Specialist of I Degree in Orthopedic, Assistant Professor, Universitary Hospital "Mártires del 9 de Abril", Cuba \\ ${ }^{4}$ Specialist of I and II Degree in Orthopedic, Assistant Professor, Universitary Hospital "Mártires del 9 de Abril”, Cuba \\ ${ }^{5} 3 r d$ year Student of Medicine, Medical Faculty of Medical Sciences of Sagua la Grande, Cuba \\ ${ }^{6}$ Specialist of I Degree in Cirugía, Profesor Instructor, Universitary Hospital "Mártires del 9 de Abril", Cuba
}

Submission: September 02, 2020; Published: September 11, 2020

*Corresponding author: Claribel Plain Pazos, Specialist of I and II Degree in Comprehensive General Medicine, Assistant Professor, Faculty of Medical Sciences of Sagua la Grande, Villa Clara, Cuba

\section{Short Communication}

Osteoarthrosis (OA) or gonoarthrosis of the knee is a chronic disease with a high prevalence worldwide. As populations age, the number of affected increases, altering quality of life to varying degrees [1]. To determine the exact prevalence of knee $\mathrm{OA}$, the definition of the disease used, the diagnostic method (clinical and/or imaging), and the affected joint are essential, for which reason the available data are diverse. Despite this, it is described that more than $50 \%$ of the population older than 65 years presents some type of OA, the most affected joint being the knee, with an incidence of $240 / 100,000$ people/year [2]. This disease causes mechanical pain that is usually related to stiffness and progressively causes loss or decrease of joint function. As it is a condition that causes pain and progressive functional limitation, it is also a constant reason for medical consultation with the resulting high costs for care and treatment, a common factor detrimental to the lifestyle that affects the quality of life of the patient related to their health [3]. Among the recognized risk factors are age and female sex, while the genetic component has a low association with knee OA, unlike what occurs in other joints, such as the hips or hands. Weight changes have been consistently related to knee $\mathrm{OA}$, with a relative risk of 2 for overweight people and 2.96 for obese people. New systemic risk factors have been recognized in recent years staking the metabolic syndrome; the presence of 2 of its components conditions a risk of knee OA of 2.3 times, while with 3 or more components the risk rises to 9.8 times [2].
Treating this disease has been difficult and it is not without side effects that can be dangerous. Due to its chronicity, it requires prolonged treatments that potentiate the collateral effects and raise costs. The management of $\mathrm{OA}$ has focused on modifying symptoms, predominantly pain relief. The appropriate strategy to repair damaged articular cartilage will need to act on multiple disease mechanisms. Despite promising research, to date there is no drug, whose effects have been confirmed by long-term studies, capable of modifying the structural damage of knee osteoarthritis [4]. Some authors advocate the application of conservative treatment to improve symptoms in patients suffering from this disease. Conservative treatment takes into account "nonpharmacological" and pharmacological methods of ambulatory management of $\mathrm{OA}$, based mainly on lifestyle modifications, rehabilitation, footwear, orthoses, support devices, analgesics, "non-steroidal" anti-inflammatory drugs, chondroprotective agents, intra-articular steroid use and viscosupplementation $[4,5]$. All these treatments, although they produce clinical improvement in the patient, only produce short-term relief and require continuity of treatment for long periods, with the consequent production of adverse effects and complications. One of the problems common to all treatments is their limited long-term effect; According to the studies reviewed, there are no studies of effectiveness after more than six months [5].

Another variant of conservative treatment is the application of plasma rich in growth factors, in studies carried out by different 
authors it was shown that it is an effective and safe procedure; with which only mild complications are recorded [1,5]. Before reaching a large and expensive surgical intervention, plateletrich plasma is a treatment of choice in gonoarthrosis for the improvement of symptoms, although it does not eliminate the disease. For the surgical management of knee OA, different methods are invoked, among which we can mention Arthroscopy with different techniques such as joint lavage, microfactures, osteophyte resection, synovectomy and chondroplasties [6]; With these procedures, clinical improvement of the patient can be achieved by delaying joint replacement. Another treatment option is Osteotomy, osteotomies at the knee level are indicated in those cases with varus or valgus deformities in which an overload is demonstrated in some of the compartments, and which are accompanied by symptoms. High tibial osteotomy can be a preventive procedure that seeks to prevent OA progression [6]. But this surgical technique has several limitations: the age of the patients must be less than 60 years, they must not be obese, they must have a knee flexion greater than $90^{\circ}$ [7], the degree of involvement of the articular surfaces of the knee must be within the Alhbäck classification [8] in type I, II and III and cannot suffer disabling degenerative diseases [7].

When the degree of involvement of the articular surfaces of the knee is IV and V-according to the aforementioned classification - the surgical indication is unicompartmental or total knee arthroplasty. This procedure makes patient care much more expensive, due to the complications it sometimes brings with it $[6,7]$. This procedure is reserved for those cases in which conservative measures or previous surgical treatments have failed to control the progression of the disease, nor the symptoms [6]. In recent years, studies by Chinese [9] and Cuban [10] specialists have published studies of the results of a new surgical technique called fibular ostectomy, which consists of a proximal fibular ostectomy (PPO) of approximately 2 centimeters, carried out carried out between 6 and 10 centimeters below the head of the fibula, in order to decompress the internal compartment in the painful genus varus and in this way relieve the patient's pain, improve the patient's function and gait with minimal resources and a faster recovery from it [10].

Surgical indications for performing PPO are the same as for osteotomy except for age and bone characteristics, since the osteotomy requires good bone quality from the patient, hence PPO is a useful variant in patients with OA of knee 60 years of age or older, which due to the age element is not feasible to perform the osteotomy [11], in the case of this new surgical technique, the patient is incorporated in less than 24 hours after the surgical act, not requiring support with canes and with full support of the affected limb; no expenses are required for osteosynthesis or prosthesis material, which really makes this type of procedure more expensive to improve the patient's quality of life. The problems of care by the family and the complications that originate these types of procedures such as infections, breakage of the prosthesis or application of immobilization with a cast disappear, being a relief for the patient, the family and society [10]. The treatment option to be used in knee OA depends on the patient's symptoms and his physical conditions. The main goal of treatment is pain relief and functional improvement with the least possibility of complications. In this case, PPO is a good treatment option.

\section{References}

1. Morales C, Pérez E, Galindo A (2019) Osteoartrosis de rodilla. Tratamiento con plasma rico en plaquetas. Reporte de 29 casos. Revista médica (Colegio de Médicos y Cirujanos de Guatemala) 158(1): 45-46.

2. Martínez FR, Martínez FC, Calvo RR, Figueroa PD (2015) Osteoartritis (artrosis) de rodilla. Rev ChilOrtopTraumatol 56(3): 45-51.

3. Viteri TFJ, Muñoz SDA, Rosales PGJ, Hernández IJP, Jaramillo VJS, et al. (2019) Osteoartrosis. Una revisión de literatura. Revista Cubana de Reumatología 21(3):1-11.

4. Álvarez LA, García LY, Mariño FJ (2004) Tratamiento conservador de la osteoartritis de rodilla. RevCubana Ortop Traumatol 18(1): 47-52.

5. Lugo GAO, Arce GMA, Castillo OGJ, García QR, Sanchez GA, et al. (2018) Suo de plasma rico en factores de crecimiento en pacientes con osteoartritis de rodilla. Acta Médica del Centro 12(2): 130-139.

6. Chalem CM, Arango PCE, Diaz CME, Duperly SJ, Forero FJP, et al. (2018) Recomendaciones sobre diagnóstico, prevención y tratamiento farmacológico y no farmacológico de la osteoartritis (OA) de rodilla. Revista Colombiana de Medicina Física y Rehabilitación 27(2): 160184.

7. Pancorbo SEA (2018) Osteotomias alrededor de la rodilla. Rev Cubana OrtopTraumatol 32(1): 1-4.

8. Ahlbäck S (1968) Osteoarthrosis of the knee. A radiographic investigation. ActaRadiolDiagn 277:7-72.

9. Zong YY, Wei C, Cun L, et al. (2015) Medial Compartment Decompression by Fibular Osteotomy to Treat Medial Compartment Knee Osteoarthritis: A Pilot Study. Orthopedics 38(12): e1110-e1114.

10. Pancorbo SEA, Ceballos MA, Martín TJ, Quesada JP, Cruz AR, et al. (2017) Osteotomía del peroné, nueva técnica quirúrgica en el genu varo doloroso. Proceder y presentación de dos casos. Rev.Med. Electrón. 39(4): 966-974.

11. Guyen PT, Álvarez LA, Aquino MFD (2018) Ostectomía parcial del peroné y artroscopia en la gonartrosis medial con deformidad en varo 22(2): 244-251. 
This work is licensed under Creative Commons Attribution 4.0 License

DOI: 10.19080/OROAJ.2020.17.555951
Your next submission with Juniper Publishers will reach you the below assets

- Quality Editorial service

- Swift Peer Review

- Reprints availability

- E-prints Service

- Manuscript Podcast for convenient understanding

- Global attainment for your research

- Manuscript accessibility in different formats ( Pdf, E-pub, Full Text, Audio)

- Unceasing customer service

Track the below URL for one-step submission https://juniperpublishers.com/online-submission.php 